\title{
Co-occurrence of anatoxin-a and microcystins in Lake Garda and other deep perialpine lakes
}

\author{
Leonardo Cerasino, Nico Salmaso \\ Department of Sustainable Agro-ecosystems and Bioresources, Research and Innovation Centre, Fondazione Edmund Mach, \\ Via E. Mach 1, 38010 San Michele all'Adige, Italy
}

\begin{abstract}
Cyanotoxins are a global concern in freshwaters and eutrophication and climate changes can have synergistic effects in exacerbating the problem. The deep perialpine lakes are a group of lakes of huge economic and naturalistic importance located at the border of the Alps. At the southern border of the Italian and Swiss Alps, the largest waterbodies include the lakes Garda, Iseo, Como, Lugano and Maggiore (Deep Subalpine Lakes, DSL). Together with eutrophication (during the 1960s and 1970s) and re-oligotrophication (from the 1990s onward) these lakes have been experiencing warming and increase of the water column stability. These changes had a strong impact on the phytoplankton (including cyanobacteria) community. Four DSL (lakes Garda, Iseo, Como and Lugano) have been studied with the aim of comparing their toxic potential. For one of them (Lake Garda) an 8 years survey was conducted, allowing a long-term trend analysis. Toxin analysis was conducted on a monthly basis by targeted LC-MS/MS. A screening for anatoxins, cylindrospermopsins, saxitoxins, microcystins (MCs) and nodularins was carried out. Among all the listed toxins, only one anatoxin and five MCs were detected in the lakes. In particular, the alkaloid anatoxin-a (ATX) was found dominant in lakes Garda, Iseo and Como, and absent in Lake Lugano; the MC-[D-Asp3]RR was found as the most abundant MC in all four lakes. Four other less abundant MCs were also found. The two major toxins are produced by two different cyanobacteria, Tychonema bourrellyi (J.W.G. Lund) Anagnostidis \& Komárek and Planktothrix rubescens (De Candolle ex Gomont) Anagnostidis \& Komárek, which share however a number of ecological traits. Peaks of these toxins occurred in warmer months (typically between May and September) in the thermocline layer (around $20 \mathrm{~m}$, in the considered lakes). In summer 2016, the highest concentrations of ATX and total MCs were registered in Lake Iseo (1100 and $430 \mathrm{ng} \mathrm{L}^{-1}$, respectively), while in the other lakes values were approximately twice lower. In the lakes where it was present, ATX peak levels were much higher than MCs, thus highlighting the necessity of including ATX in the procedures of risk assessment. The importance of ATX is expected to further grow in the future with respect to MCs, as demonstrated by the long-term trend analysis carried out in Lake Garda that showed a clear decline for MCs from 2009 till 2016 and a relative constancy of ATX.
\end{abstract}

\section{INTRODUCTION}

Because of the growing anthropogenic impact, cyanobacterial blooms in freshwaters are increasing worldwide (Huisman et al., 2018). Eutrophication is the main driver of this phenomenon (Conley et al., 2009), but climatic change also plays an important role in favoring the abnormal growth of cyanobacteria (Mantzouki et al., 2018a; Meriluoto et al., 2017a; Moss et al., 2011; Rigosi et al., 2014).

Many cyanobacterial species have the capability of producing toxic metabolites (cyanotoxins), like the hepatotoxic microcystins (MCs) and nodularins (NODs), the cytotoxic cylindrospermopsins (CYNs), the neurotoxic anatoxins (ATXs) and saxitoxins (STXs) (Carmichael, 1994; Meriluoto et al., 2017b; Metcalf and Codd, 2012). The abundance of toxins during a cyanobacterial bloom is not directly and exclusively related to the biomass (Mantzouki et al., 2018a; Salmaso et al., 2014), but depends on several factors: first of all, the species which is involved in the bloom, as different species produce different toxins (Cerasino et al., 2017; Meriluoto et al., 2017b); and, secondly, the proportion of toxic strains within the cyanobacterial population (Capelli et al., 2017; Kurmayer et al., 2004). A third factor, represented by the environmental factors influencing the metabolic pathway of the toxin production, must be mentioned, although the mechanisms and the actual effects of abiotic and biotic factors are still a matter of debate (Neilan et al., 2013).

The presence of cyanotoxins in lakes can pose problems to water utilization and procedures for the management of the risks are regulated in many countries (Chorus, 2012; Ibelings et al., 2014).

The Italian perialpine district comprises five large and deep lakes (namely, lakes Garda, Iseo, Como, Lugano, and Maggiore; DSL), which globally constitute over the $80 \%$ of the freshwater reserves in Italy. DSL have experienced eutrophication in the 1960s and 1970s. The degradation of water quality was effectively contrasted by protection measures put in place since the 1980s. In the last two decades, nutrients levels (of phosphorous in particular) have declined consistently. Together with eutrophication and re-oligotrophication, these lakes have been experiencing also common physical changes, represented by a significant warming and increased stability of the water column (Anneville et al., 2005; Gallina et al., 2013; Salmaso et al., 2020, 2018b). Both chemical and physical changes have deeply influenced the phytoplankton community. Cyanobacteria have declined in recent years and their structure has changed. For instance, among toxic cyanobacteria, a decline of the mesotrophic Planktothrix 
rubescens (De Candolle ex Gomont) Anagnostidis \& Komárek (MCs producer) was observed, which was partially replaced by Tychonema bourrellyi (J.W.G.Lund) Anagnostidis \& Komárek (ATXs producer). The two cited toxic species are part of the cyanobacterial populations of DSL, which also comprise Microcystis aeruginosa (Kützing) Kützing, Aphanizomenon flos-aquae Ralfs ex Bornet \& Flahault, and Dolichospermum lemmermannii (Richter) P.Wacklin, L.Hoffmann \& J.Komárek (Cerasino et al., 2017; Salmaso, 2019; Salmaso et al., 2018a). Analysis conducted on strains isolated form DSL (Cerasino et al., 2017) have shown that $M$. aeruginosa and $P$. rubescens could produce MCs, T. bourrellyi anatoxin-a (ATX), while A. flos-aquae and D. lemmermannii resulted to be not toxic. A successive study (Capelli et al., 2017) showed also that the lack of toxicity of $D$. lemmermannii strains isolated in DSL was due to the lack of both MCs and ATXs encoding genes.

A field study was conducted in 2009 in order to evaluate the toxic potential of cyanobacterial populations in DSL (Cerasino and Salmaso, 2012); the study showed that i) MCs were present in all DSL, with a dominance of demethylated variants; and ii) ATX was present in four out of five lakes, the exception being represented by Lake Lugano. Moreover, in the study, the differences in toxin concentrations among lakes were interpreted in terms of different lake characteristics; more specifically, MCs levels were positively related to nutrients' concentrations, while ATX levels were more dependent on the water temperature, thus suggesting eutrophication and climate change as factors shaping the cyanotoxins diversity in different ways. Climatic factors have been also recently reported as the main driver of cyanotoxins distribution at European level (Mantzouki et al., 2018b).

Since 2009, cyanotoxins in Lake Garda have been regularly measured, thus allowing following the changes of the toxic potential of the lake. If the effects of the oligotrophication of Lake Garda and the other DSL is certainly protective against cyanobacteria proliferation, the effects of climate change are more difficult to assess, due to the many ways they can operate, for example increasing the water temperature and water column stability, increasing $\mathrm{CO}_{2}$, and altering the hydrology (Callieri et al., 2014; Pareeth et al., 2017; Visser et al., 2016). The availability of a time series for cyanotoxins data collected with uniform methodology is a valuable tool for understanding past changes and foreseeing future trajectories. This information is of great importance for the management of the lake, as the risks posed by MCs are different from those posed by ATX, and also the measures for contrasting these risks are different (Ibelings et al. 2014). Moreover, considering the high chemical diversity of cyanotoxins, the analytical method should be adequate to describe as many toxins as possible.
The objectives of this contribution include: i) critical evaluation of the results obtained from the analysis of cyanotoxins conducted with a monthly frequency in Lake Garda from 2009 till 2016; ii) the comparison of the longterm data collected in Lake Garda with those collected in other three DSL (lakes Iseo, Como and Lugano) in 2016. Data collected allow highlighting changes in the toxic profile in the considered lakes and contributing to define correctly the risks related to possible cyanobacterial blooms.

\section{METHODS}

\section{Sampling sites and sample collection}

The study was conducted in four lakes located in the Italian perialpine region: Garda, Iseo, Como and Lugano. These lakes belong to the group of the DSL, which comprises also Lake Maggiore. The maximum depth of these lakes span between $251 \mathrm{~m}$ of Lake Iseo and $410 \mathrm{~m}$ of Lake Como, their altitude between $65 \mathrm{~m}$ of Lake Garda and $271 \mathrm{~m}$ of Lake Lugano, and their volume between $4.7 \times 10^{9}$ $\mathrm{m}^{3}$ of Lake Lugano and $49 \times 10^{9} \mathrm{~m}^{3}$ of Lake Garda. Lakes Garda, Iseo and Como host research stations belonging to LTER (Long Term Ecological Research) Italian network, and are part of the same macrosite ("Southern Alpine lakes", IT08-000-A, http://www.lteritalia.it/).

All these lakes underwent an eutrophication process between the 1960s and 1980s (Mosello et al., 1997); in the 1990s nutrient levels started to decrease and currently lakes Garda and Como can be classified as oligomesotrophic and lakes Iseo and Lugano as meso-eutrophic (Mosello et al., 2010; Salmaso et al., 2020).

Samples were taken with a monthly interval at the center of the lakes at discrete depths. Lake Garda was sampled from September 2009 until December 2016 (88 samplings) at four depths $(0,10,20,60 \mathrm{~m})$; an additional sampling at $40 \mathrm{~m}$ was carried out only in 2016 , in analogy with samplings carried out in the same year in lakes Iseo, Como and Lugano, where samples were taken from five depths $(0,10,20,40$, and $60 \mathrm{~m})$. In 2016, Lake Iseo was sampled from February until December (12 samplings), Lake Como from April until December (10 samplings), and Lake Lugano only in June. At every depth, approx. $2.5 \mathrm{~L}$ of water were collected and stored in an amber glass bottle. In the lab, the water was filtered on $47 \mathrm{~mm}$ diameter GF-C filters (Cytiva Whatman), which were kept at $-20^{\circ} \mathrm{C}$ until the analysis of toxins.

\section{Toxin analysis}

LC-MS is the most powerful technique in cyanotoxins profiling thanks to the combination of high sensitivity and high selectivity (Meriluoto et al., 2017b). The LC-MS methods used in this investigation have been setup through most of the standards currently available in the 
market, which represent by far the most common and frequent. These methods have been applied previously on cultured strains of cyanobacteria taken from the lakes considered in this study and proved to be adequate to catch the toxin diversity in these environments (Cerasino et al., 2017).

Filters were treated with $6 \mathrm{~mL}$ of acetonitrile/water mixture $(60 / 40 \mathrm{v} / \mathrm{v})$ containing $0.1 \%$ formic acid; the sample was first homogenized (Omni TH probe homogenizer, Omni-Inc.) for $5 \mathrm{~min}$ and then sonicated (Omniruptor4000 probe sonicator, Omni-Inc.) for $4 \mathrm{~min}$, using $160 \mathrm{~W}$ power in pulsed mode $(50 \%)$. The solution was separated from the pellet by centrifugation (EBA 20, Hettich) for $6 \mathrm{~min}$ at $9850 \mathrm{G}$. The pellet was then treated with a second aliquot of extraction mixture $(6 \mathrm{~mL})$ and sonicated. After centrifugation, the extraction liquid was added to the previous and vortexed. A $2 \mathrm{~mL}$ aliquot was filtered on $0.2 \mu \mathrm{m}$ pore size RC syringe filters (Phenomenex), and analyzed by LC-MS/MS.

Samples underwent two distinct LC-MS/MS analyses, one specific for peptides (MCs), and one specific for alkaloids (ATXs, CYNs, STXs). Both analyses were performed using a Waters Acquity UPLC system, directly coupled to a SCIEX 4000 QTRAP hybrid mass spectrometer equipped with a turbo ion spray interface. Mass detector was operated in scheduled MRM mode using positive electrospray ionization $(\mathrm{ESI}+)$. Details about protocols, instrumental settings and method performances can be found in Cerasino et al. $(2017,2016)$.

The analytical protocols were optimized for the detection and quantification of the peptidic toxins MCRR, [D-Asp3]-RR, [D-Asp3]-HtyrR, YR, LR, [D-Asp3]-LR, WR, LA, LY, LW, LF, NOD-R and of alkaloids ATX, HomoATX, CYN, saxitoxin (STX), decarbamoylSTX, NeoSTX, GTX 1, GTX4, GTX5, C1 and $\mathrm{C} 2$. These toxins were individually quantified in each sample. Total MCs was calculated as the sum of each single $\mathrm{MC}$ variant (on a mass basis).

\section{Cyanobacteria abundances from metagenomic data}

The relative abundances of $T$. bourrellyi and $P$. rubescens were obtained from the datasets published (ENA study accession PRJEB22244) and analyzed by Salmaso et al. (2018a). The abundances of bacteria species (including cyanobacteria) were estimated as the number of reads after rarefaction of the OTU table without replacement to 38000 sequences per sample. In this work, the abundances of Tychonema and Planktothrix were estimated as the \% of reads on the total reads of cyanobacteria.

\section{Statistical analysis}

Data and graphical analyses were performed by using the R package 3.6.0 (R Core Team, 2019). The long-term trends of ATX and MCs based on the data recorded in Lake Garda between 2009 and 2016 in the 0-20 m layer were evaluated using generalized additive models (GAM), using the package mgcv in R (R Core Team, 2019), cfr. Salmaso et al. (2016). The models were described by the effective degrees of freedom (edf); high edf values indicate higher non-linear smoothing spline (Zuur et al., 2009).

\section{RESULTS}

\section{Toxins levels in Lake Garda in the 2009-2016 period}

In Lake Garda the presence of both toxin groups (MCs and ATXs) was confirmed. Total MCs and ATX concentrations are graphically reported in Fig. 1 A,B. Seasonal toxin peaks, generally lasting a couple of months, were followed by longer periods (10 months, on average) in which toxins were present at concentrations typically two orders of magnitude lower. During the peaks, total MCs reached values higher than $100 \mathrm{ng} \mathrm{L}^{-1}$ in 2010, 2011, and 2015 (230, 200, and $190 \mathrm{ng} \mathrm{L}^{-1}$, respectively); in the remaining years, peak concentrations showed a decreasing trend from 90 (in 2009) to $20 \mathrm{ng} \mathrm{L}^{-1}$ (in 2016). On the other hand, for ATX the peak concentrations showed values above $1000 \mathrm{ng} \mathrm{L}^{-1}$ from 2011 until 2014 (around 1300 in 2011 and 2012, 2700 in 2013, 2000 in 2014).

A trend analysis, reported in Fig. 1C, showed that, in the observed period, ATX underwent an increasing tendency from 2009 until 2013, followed by a decreasing one in the following years. MCs (Fig. 1D), instead, underwent a dramatic decrease: from higher values in the 2009-2011 period, concentrations dropped down to a minimum in the 2014-2016 period, with the remarkable exception of 2015.

The annual toxin peaks occurred in different periods for ATX and MCs. As shown in Fig. 1 E,F, ATX peaks typically were centered in June, while MCs peaks in August. The different temporal distribution of the two classes of toxins contributed to confirm that, in Lake Garda, they were produced by different organisms: ATX by $T$. bourrellyi and MCs by $P$. rubescens. In fact, the comparison of toxin concentrations and cyanobacteria abundances derived from metagenomic data showed that that ATX and MC levels were linearly correlated to $T$. bourrellyi and $P$. rubescens reads, respectively (Fig. 2).

Fig. 3 A,B reports the vertical distributions of ATX and MCs in Lake Garda. It clearly shows that the highest concentrations of both ATX and MCs were present at 20 $\mathrm{m}$ depth. Moreover, the figure shows that, during peaks, toxins are confined in a narrow layer around $20 \mathrm{~m}$. For ATX there was an early peak in April $\left(900 \mathrm{ng} \mathrm{L}^{-1}\right)$ and a second one, less intense, in June $\left(500 \mathrm{ng} \mathrm{L}^{-1}\right)$. For MCs, the peak was registered in September when a concentration of ca. $50 \mathrm{ng} \mathrm{L}^{-1}$. 

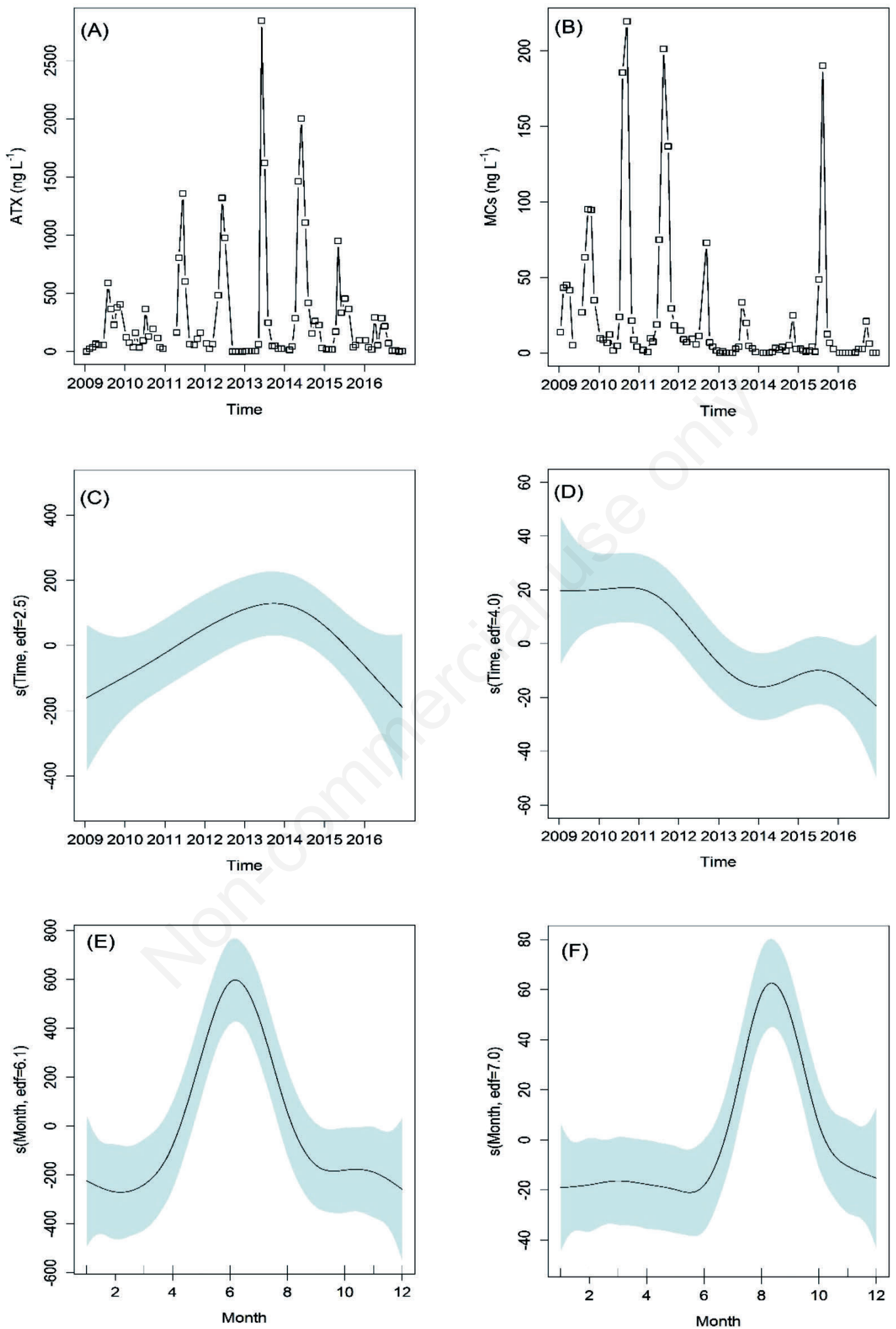

Fig. 1. Data about cyanotoxin presence in Lake Garda from 2009 until 2016. Monthly data about ATX (A) and total MCs (B) concentrations in the lake (0-20 mean values). Trend analysis for ATX (C) and total MCs (D). Seasonality of ATX (E) and MCs (F). In C-F, the approximate significance of smooth terms (Wood, 2006) is significant $(\mathrm{P}<0.05)$. 


\section{Toxins levels in lakes Iseo, Como and Lugano in 2016}

Toxin levels recorded for Lakes Iseo, Como and Lugano are graphically reported in Fig. 3 C-F. Similarly to Lake Garda, the analyses confirmed the presence of both ATX and MCs in Lakes Iseo and Como. In Lake Iseo (Fig. $3 \mathrm{C}, \mathrm{D})$, relevant concentrations of toxins were recorded from May till June, while in the rest of the year values were between 0 and $200 \mathrm{ng} \mathrm{L}^{-1}$ for ATX and between 0 and 20 ng $\mathrm{L}^{-1}$ for total MCs. In May and June peak levels of ATX (1300 and $1100 \mathrm{ng} \mathrm{L}^{-1}$ ) and total MCs (400 and $430 \mathrm{ng}$ $\mathrm{L}^{-1}$ ) were reached at $20 \mathrm{~m}$ depth. Differently from MCs, in June ATX was spread toward the water surface, where a concentration of $560 \mathrm{ng} \mathrm{L}^{-1}$ was recorded.

In Lake Como (Fig. 3 E,F), we observed a similar pattern for toxin distribution, with highest values between June and August for ATX and July and August for MCs. The highest concentrations of toxins were registered in June for ATX (530 ng L $\left.{ }^{-1}\right)$ and in August for MCs (53 ng
$\mathrm{L}^{-1}$ ) at the same depth of $20 \mathrm{~m}$. In June, ATX was uniformly present in the 0-20 m layer, and concentration at the lake surface was $300 \mathrm{ng} \mathrm{L}^{-1}$.

In Lake Lugano, which was sampled only in June, MCs were found at levels of 2, 44, 17, 5 and $2 \mathrm{ng} \mathrm{L}^{-1}$ (as total MCs) at 0, 10, 20, 40 and $60 \mathrm{~m}$ depth, respectively. Noteworthy, ATX was not detected at all or in traces.

\section{Toxin diversity}

While ATX was the only alkaloid toxin found in the investigation, the peptidic toxins showed more diversity. In fact, five MC variants were found to be present, namely [D-Asp3]-RR, [D-Asp3]-LR, [D-Asp3]-HtyR, LR and RR. Tab. 1 reports the abundances of these toxins in the different lakes. In all lakes, [D-Asp3]-RR was always found as dominant over the others, with abundance always over $60 \%$ of the total MC content. The other variants were detected with lower frequency and lower abundancies: [D-Asp3]-

Tab. 1. Relative abundances of MC variants in the four lakes. For each variant the minimum and the maximum values recorded in the observation period are reported.

\begin{tabular}{|c|c|c|c|c|c|}
\hline \multirow[t]{2}{*}{ Lake } & \multicolumn{5}{|c|}{ MC variants (\%) } \\
\hline & [D-Asp3]-RR & [D-Asp3]-LR & [D-Asp3]-HtyR & LR & $\mathbf{R R}$ \\
\hline Garda & $70-100$ & $0-20$ & $0-5$ & $0-2$ & $0-2$ \\
\hline Iseo & $70-97$ & $0-12$ & $0-45$ & $0-10$ & $0-5$ \\
\hline Como & $60-100$ & $0-10$ & $0-30$ & $0-60$ & $0-1$ \\
\hline Lugano & $75-92$ & $4-10$ & $1-4$ & $0-4$ & $0-2$ \\
\hline
\end{tabular}
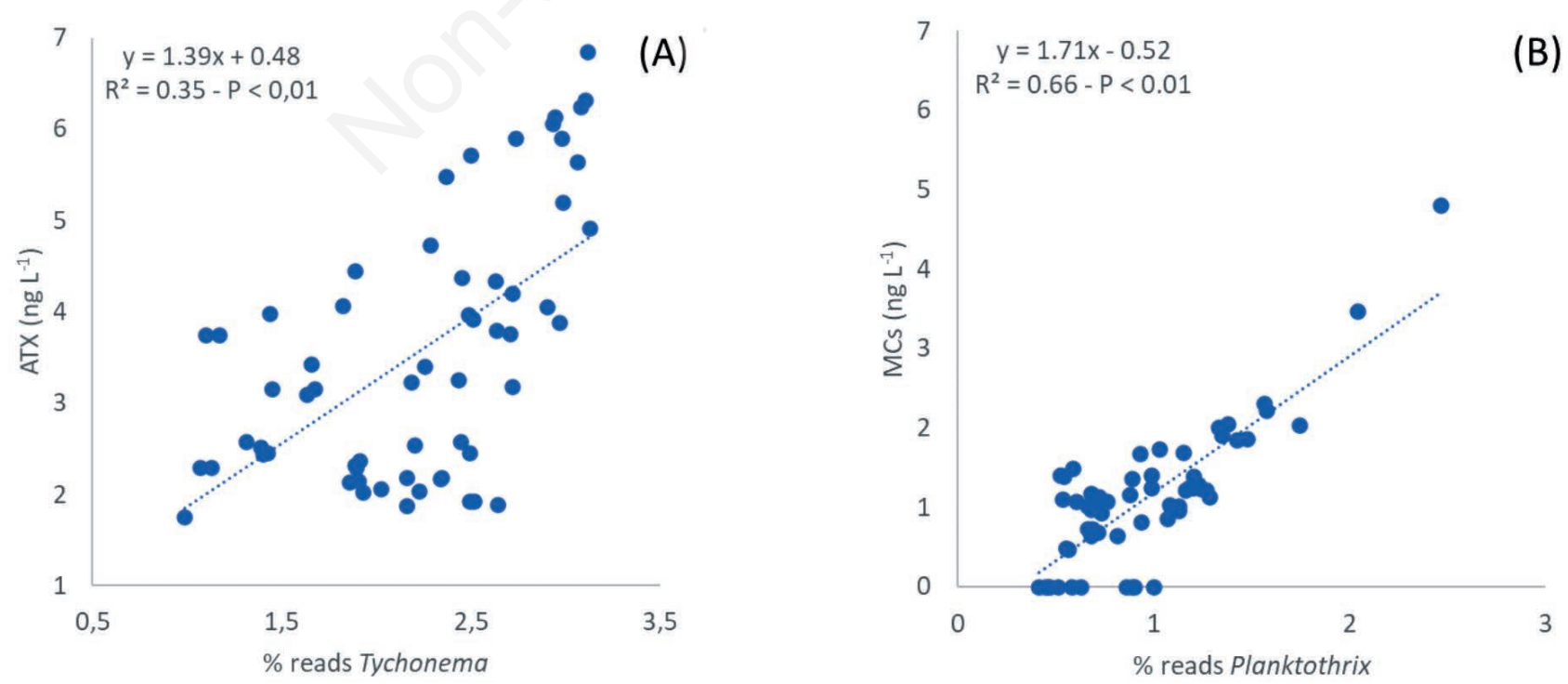

Fig. 2. Relationship between toxins concentration and cyanobacterial abundances (estimated as fraction of reads in metagenomics analysis) in Lake Garda (2014-2015 only). Both cyanobacteria abundances and toxins concentrations were double square transformed; relationships were highly significant $(\mathrm{P}<0.01)$. 

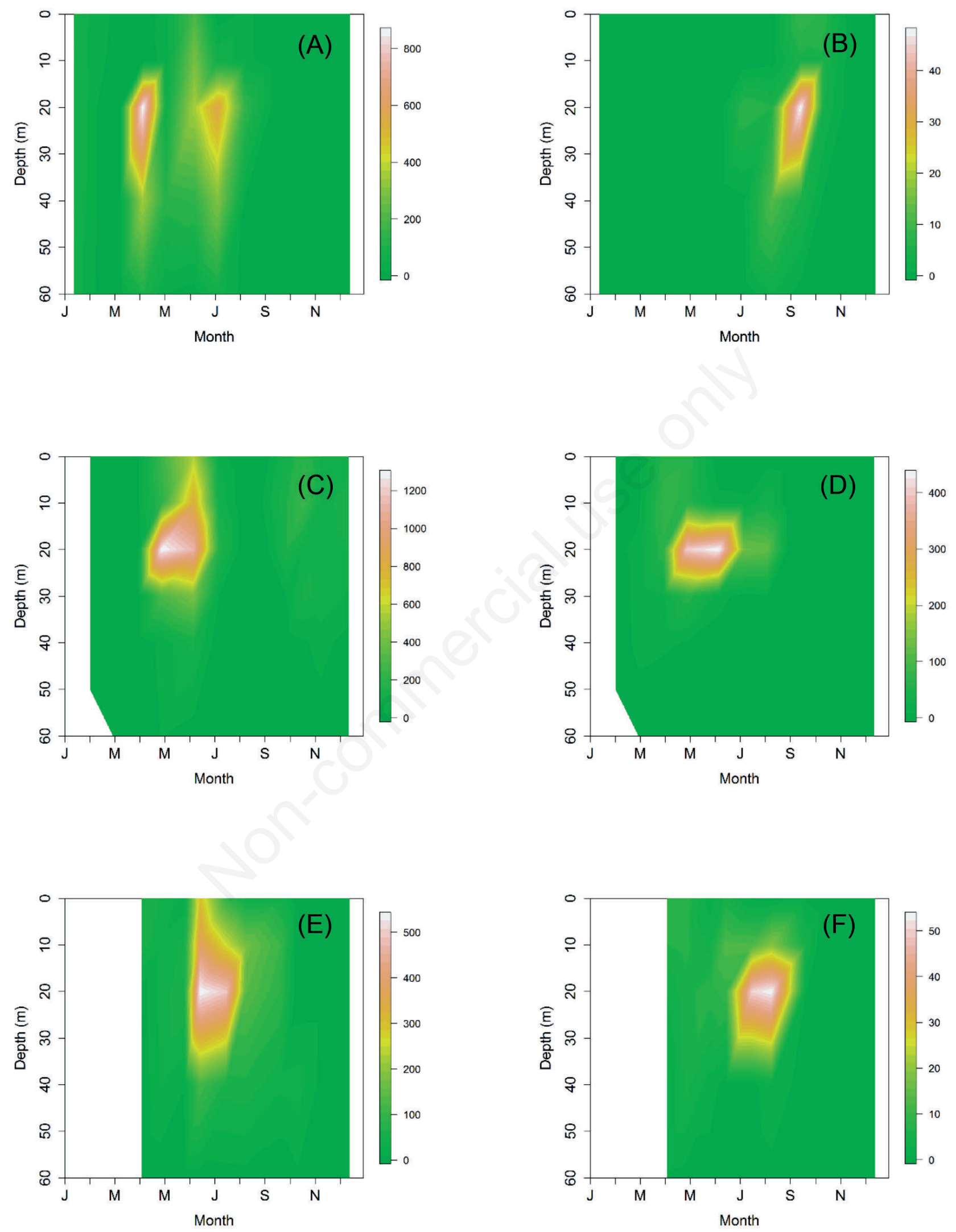

Fig. 3. Vertical distribution of toxins measured in 2016 in lakes Garda (A,B), Iseo (C,D), and Como (E,F). ATX on the left hand side, total MCs on the right hand side. 
LR represented the second abundant (between 0 and $20 \%$ ) in Lake Garda; this toxin reaches maximum $10-12 \%$ in the other lakes. [D-Asp3]-HtyR reached remarkable abundances in lakes Iseo and Como (45 and 30\%, respectively), while it was always below $5 \%$ in lakes Garda and Lugano. MC LR was always present in low abundances (below $4 \%$ ) in lakes Garda and Lugano, but reached $10 \%$ in Lake Iseo and $60 \%$ in Lake Como. Finally, MC RR was found in very low abundances in all lakes (below 5\%). In Fig. 4, a comparative picture of the average MC diversity in the four lakes is reported. All lakes are dominated by the [D-Asp3]-RR variant. In Lake Garda all other variants account for less than $8 \%$. [D-Asp3]-HtyR variant showed a higher contribution in lakes Iseo and Como (11 and 8.7\%, respectively), [D-Asp3]-LR in Lake Lugano $(8.7 \%)$, and LR in Lake Iseo $(6.9 \%)$.

[D-Asp3]-HtyR; 2.4

Garda

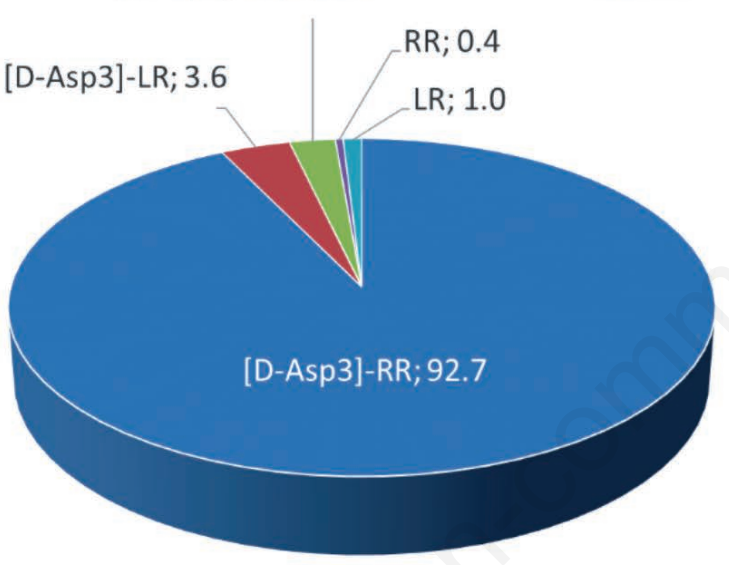

[D-Asp3]-HtyR; 8.7

Como

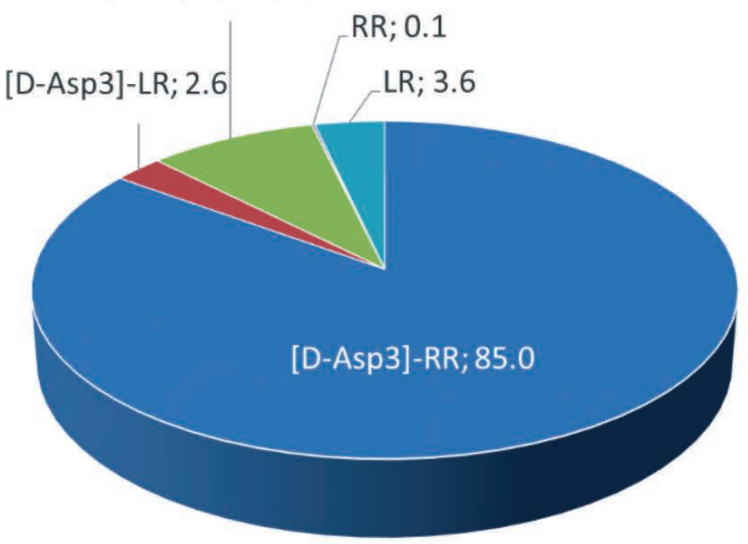

\section{DISCUSSION}

\section{Toxin dynamics in Lake Garda}

In the survey conducted in 2009 (Cerasino and Salmaso, 2012), MCs concentrations in Lake Garda were very low (maximum summer value was ca. $100 \mathrm{ng} \mathrm{L}^{-1}$ ), thus not representing a relevant issue. The survey for the first time revealed that another toxin, ATX (an alkaloid with potent neurotoxic activity) was present in the lake with concentrations up to 5 times higher with respect to MCs: in 2009 a peak of $600 \mathrm{ng} \mathrm{L}^{-1}$ was found. This first observation triggered a series of investigations aimed at clarifying the origin of this toxin, finally leading to the identification of $T$. bourrellyi as the only ATX producer in the lake (Shams et al., 2015). This species seems to be

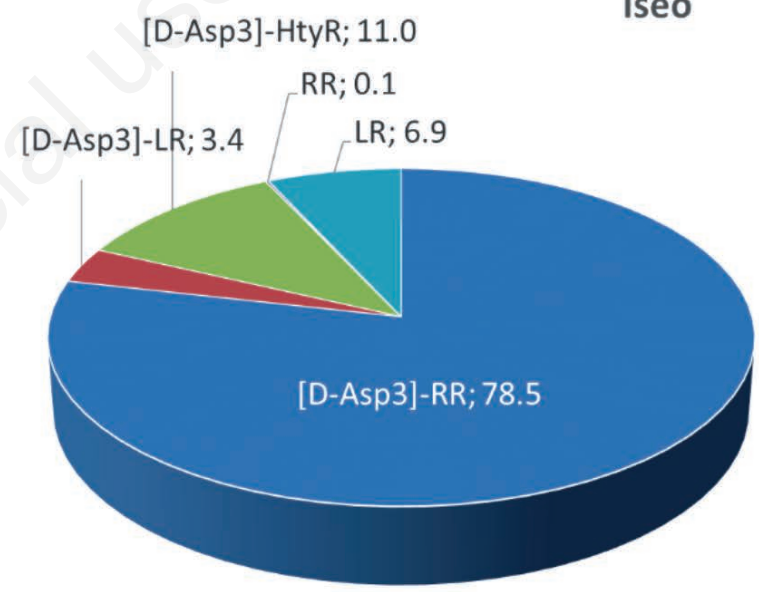

[D-Asp3]-HtyR; 2.1

Lugano

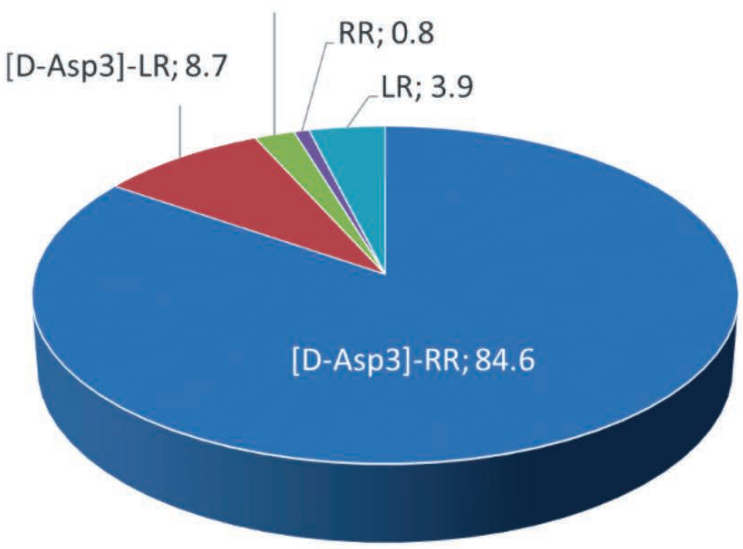

Fig. 4. Averaged relative abundances (\%) of different MC variants in the investigated lakes. 
outcompeting the MCs producer P. rubescens in Lake Garda and in other DSL (Salmaso et al., 2018b; Salmaso et al., 2016). The data presented here (cfr. Fig. 1), showed that in the eight years of observations, MCs and ATX still continued to be both present in Lake Garda, with ATX summer maxima always higher than MCs'. From 2011 till 2014, ATX reached concentrations higher than $1 \mu \mathrm{g} \mathrm{L}^{-1}$ (the highest being $2.7 \mu \mathrm{gL}^{-1}$ in 2013), which is considered a threshold limit for drinking water in some countries; MCs, instead, remained always below $0.25 \mu \mathrm{g} \mathrm{L}^{-1}$, abundantly lower than $1 \mu \mathrm{gL}-1$ set as threshold in drinking waters (Ibelings et al., 2014). It is worth noting that toxin concentrations fell to very low values outside the warm season (May-October). MCs went often undetected in cold months and ATX rarely exceeded 50 $n g \mathrm{~L}^{-1}$. Moreover, the toxin peaks were always limited to a narrow layer in the water columns, typically around 20 $\mathrm{m}$, where producing organisms (T. bourrellyi and $P$. rubescens) find the best conditions to grow. It is worth noting that in all years ATX and MCs summer peaks in Lake Garda are not synchronous. As reported in Fig. 1, ATX maxima generally occurred a couple of months earlier than MCs maxima, thus determining two distinct situations, an early one in which the cyanotoxins risk is due to ATX and a late one linked to the prevalence of MCs. The evidence of this time separation can be helpful from a management point of view. Finally, giving a global look at the data collected between 2009 and 2016 in Lake Garda, we can conclude that a decreasing trend is observable for both ATX and MCs. This was more pronounced and clearer for MCs (Fig. 1D) for which, excluding the exceptional 2015 year, a dramatic decline in summer concentrations was registered. For ATX, on the other hand, the decline was evident only from 2014 onward, while there was a remarkable increase in previous years. These two toxins, although showing contrasting trends, globally seemed to be less and less present in the lake.

\section{Toxins in the other DSL}

The results obtained from the 2016 sampling campaign in Lakes Iseo, Como and Lugano confirmed some evidences already obtained in 2009 (Cerasino and Salmaso, 2012). In fact, MCs were found in all the lakes, while ATX was detected in lakes Iseo and Como, but not in Lake Lugano. The peak of toxin concentrations registered in Lake Iseo in 2016 was almost three times higher than those recorded in 2009 for both ATX and MCs, when ca. 400 and $100 \mathrm{ng} \mathrm{L}^{-1}$, respectively, were found. In Lake Como, while MCs in 2016 were much lower than in 2009 (50 vs $\left.200 \mathrm{ng} \mathrm{L}^{-1}\right)$, ATX levels remained similar $\left(500\right.$ v. $\left.440 \mathrm{ng} \mathrm{L}^{-1}\right)$. Finally, in Lake Lugano the MCs level showed a slight decrease from 100 to $44 \mathrm{ng} \mathrm{L}^{-1}$. Differently from Lake Garda, peaks of ATX and MCs in Lakes Iseo and Como are less separated on a temporal scale (Fig. 2). In Lake Como the two peaks are almost coincident (with maximum concentrations between May and June), while in Lake Iseo, they are only partially overlapped, with ATX starting earlier (in June) and MCs a bit later (in July). The fact that for DSL we have data only from 2016 makes it impossible to affirm that this small temporal separation of ATX and MCs is typical of these lakes.

Globally, this work suggests evidences of a decrease of MCs in Lakes Garda and Como, a stable situation in Lake Lugano, and a definite increase of MCs in Lake Iseo. Though based on a complete dataset only in Lake Garda, interestingly, these trends closely reflected the trophic status of the lakes (Rogora et al., 2018; Salmaso et al., 2020). Lakes Lugano and Iseo, which registered constant concentrations or an increase of MCs, have higher nutrients content than lakes Garda and Como, which, on the contrary, experienced a decrease in MCs. These evidences strengthen the hypothesis of a correlation between MCs (and MCs producing organisms) with nutrient levels, which was formulated in Cerasino and Salmaso (2012). Nevertheless, being based on a very limited set of data, the observations carried out in lakes Iseo, Como and Lugano will have to be confirmed by extending the periods of investigations.

On the other side, for ATX, comparing 2009 and 2016, a stable situation was documented in lakes Garda and Como, and a net increase in Lake Iseo. Overall, over eight years we observed a growing importance of ATX at the expense of MCs in the DSL. Interestingly, Lake Lugano was the only one among the DSL, in which no ATX producing cyanobacteria have been described (Capelli et al., 2018; Capelli et al., 2017; Shams et al., 2015).

\section{Toxin diversity}

Cyanobacteria can produce hundreds of different toxins. Nearly $250 \mathrm{MCs}$ and NODs (Spoof and Arnaud, 2017), 5 CYNs (Wimmer et al., 2014), 10 ATXs, 20 STXs (Kellmann et al., 2013) are reported in the literature. This diversity is caused by the high flexibility of the biosynthetic pathways, which is typical of the secondary metabolism. It is common that each toxic species produces preferentially one group of toxins (ATXs or MCs or STX) and it is also frequent that different variants of the same toxin group are produced by the same species (or strain). This happens more frequently in MCs producing cyanobacteria, in which the co-production of multiple variants is the rule. In alkaloids producing cyanobacteria, the variability is definitely lower. In experiments run on cultured cyanobacteria, we found that P. rubescens strains collected in Lake Garda produced five variants of MCs, but no alkaloids; T. bourrellyi, instead, produced only 2 alkaloids (ATX and HomoATX) and no 
MCs; D. lemmermannii did produce neither MCs nor alkaloids (Capelli et al., 2017; Cerasino et al., 2017; Salmaso et al., 2016). The MCs profile of cultured $P$. rubescens was coincident to the MCs profile found in Lake Garda in the 2009-2016 sampling campaign and in the other DSL lakes sampled in 2016, consisting in the presence of a dominant variant ([D-Asp3]-RR, higher than 78\%) and lower amounts of [D-Asp3]-LR, [DAsp3]-HtyR, RR and LR. The dominance of demethylated (D-Asp3) variants is widely considered as typical of $P$. rubescens (Rohrlack et al., 2008; Rounge et al., 2010). The other common MCs producer, also present in DSL, i.e. M. aeruginosa, has a MCs profiles in which standard non demethylated variants are dominant (namely, LR, YR and RR) (Cerasino et al., 2017). While in Lake Garda the fraction of MC-LR was about $1 \%$ of the total, in the other lakes this fraction was higher: $6.9 \%$ in Lake Iseo, 3.6\% in Lake Como and 3.9\% in Lake Lugano. These higher fractions of LR can be interpreted as a contribution of M. aeruginosa to the MCs pool, although there is the possibility that the differences among lakes is due to the presence of different chemotypes of $P$. rubescens. The constant prevalence of [D-Asp3]-RR in all the investigated lakes should be taken into consideration for the assessment of the risk for humans and animals. Currently, all the regulations are based on toxicological studies conducted on MC-LR. Very little is known about the toxicity of the RR variant, which is also very frequent, and much less about the other hundreds of variants. Although some studies have been conducted on RR variants (comprised the demethylated variants), results still do not allow deriving a conclusion about its higher or lower toxicity in comparison to the reference LR (Buratti et al., 2017; Diez-Quijada et al., 2019). In relation to the presence of ATX in DSL, it deserves particular attention because it is a potent neurotoxin that binds irreversibly to the acetylcholine receptors and blocks neurotransmission. ATX produced by benthic cyanobacteria has been responsible of several animal fatalities (Edwards et al., 1992; Faassen et al., 2012; Fastner et al., 2018).

\section{CONCLUSIONS}

The investigation has allowed describing the evolution of the cyanotoxin diversity in Lake Garda from 2009 till 2016. The monthly frequency of sampling allowed detecting seasonal variations over a period of 8 years. In general, it was found that the alkaloid ATX was the toxin with the highest concentrations, followed by [D-Asp3]MCRR. Four other MCs were commonly found but with much lower abundances. Peaks of these toxins were generally observed in warmer months at depths between 20 and 30 $\mathrm{m}$. The highest values were registered in 2013 for ATX
(2700 $\left.\mathrm{ng} \mathrm{L}^{-1}\right)$ and 2010 for total MCs $\left(230 \mathrm{ng} \mathrm{L}^{-1}\right)$, both at $20 \mathrm{~m}$. A trend analysis showed that both major toxins were subject to a decreasing trend, which was much more pronounced for MCs than ATX. As a result, currently ATX has assumed a noticeable relevance.

Lakes Iseo and Como have a situation very similar to Lake Garda: ATX is found co-dominating together with [D-Asp3]MC-RR. Lake Lugano differs from the others because no ATX has been documented; the MCs diversity is, instead, very similar. Compared to data collected in 2009, in 2016 ATX and MCs concentrations in Lake Iseo were much higher, whereas, in the other lakes, toxins levels remained similar or lower.

Overall, data show that the issue of cyanotoxins in DSL needs to take into account the presence of MCs but must face the growing importance of ATX. These toxins have different chemical and toxicological characteristics and therefore require different approaches in the risk management.

\section{ACKNOWLEDGEMENTS}

Investigations were carried out in the framework of the Italian LTER (Long Term Ecological Research) network, site Southern Alpine lakes, IT08-000-A (http://www.lteritalia.it/), with the support of G. Franzini and colleagues (ARPA Veneto), F. Buzzi (ARPA Lombardia), and B. Leoni (University of Milan Bicocca). Special thanks are due to Adriano Boscaini and the technical staff in FEM, for their support in the field and/or laboratory.

Corresponding author: leonardo.cerasino@fmach.it

Key words: Cyanotoxins; anatoxin-a; microcystins; deep perialpine lakes; Lake Garda, LC-MS.

Received: 14 November 2019.

Accepted: 23 April 2020.

This work is licensed under a Creative Commons Attribution NonCommercial 4.0 License (CC BY-NC 4.0).

${ }^{\circ}$ Copyright: the Author(s), 2020

Licensee PAGEPress, Italy

Advances in Oceanography and Limnology, 2020; 11:8677

DOI: 10.4081/aiol.2020.8677

\section{REFERENCES}

Anneville O, Gammeter S, Straile D, 2005. Phosphorus decrease and climate variability: mediators of synchrony in phytoplankton changes among European peri-alpine lakes. Freshwater Biol. 50:1731-1746. DOI: 10.1111/j.13652427.2005.01429.x 
Buratti FM, Manganelli M, Vichi S, Stefanelli M, Scardala S, Testai E, Funari E, 2017. Cyanotoxins: producing organisms, occurrence, toxicity, mechanism of action and human health toxicological risk evaluation. Arch. Toxicol. 91:1049-1130. DOI: 10.1007/s00204-016-1913-6

Callieri C, Bertoni R, Contesini M, Bertoni F., 2014. Lake level fluctuations boost toxic cyanobacterial "Oligotrophic Blooms". Plos One 9:8. DOI: 10.1371/journal.pone.0109526

Capelli C, Ballot A, Cerasino L, Papini A, Salmaso N, 2017. Biogeography of bloom-forming microcystin producing and non-toxigenic populations of Dolichospermum lemmermannii (Cyanobacteria). Harmful Algae 67:1-12. DOI: $10.1016 /$ j.hal.2017.05.004

Capelli C, Cerasino L, Boscaini A, Salmaso N, 2018. Molecular tools for the quantitative evaluation of potentially toxigenic Tychonema bourrellyi (Cyanobacteria, Oscillatoriales) in large lakes. Hydrobiologia 824:109-119. DOI: $10.1007 /$ s10750018-3513-3

Carmichael WW, 1994. The toxins of cyanobacteria. Sci. Am. 270:78-86. DOI: 10.1038/scientificamerican0194-78

Cerasino L, Capelli C, Salmaso N, 2017. A comparative study of the metabolic profiles of common nuisance cyanobacteria in southern perialpine lakes. Adv. Ocean. Limnol. 8:22-32. DOI: 10.4081/aiol.2017.6381

Cerasino L, Salmaso N, 2012. Diversity and distribution of cyanobacterial toxins in the Italian subalpine lacustrine district. Oceanol. Hydrobiol. St. 41:54-63. DOI: 10.2478/s13545-012-0028-9

Cerasino L, Shams S, Boscaini A, Salmaso N, 2016. Multiannual trend of microcystin production in the toxic cyanobacterium Planktothrix rubescens in Lake Garda (Italy). Chem. Ecol. 32:492-506. DOI: 10.1080/02757540.2016.1157175

Chorus I, 2012. Current approaches to cyanotoxin risk assessment, risk management and regulations in different countries. Federal Environment Agency: Dessau-Rosslau, Germany.

Conley DJ, Paerl HW, Howarth RW, Boesch DF, Seitzinger SP, Havens KE, Lancelot C, Likens GE. 2009. Ecology controlling eutrophication: Nitrogen and phosphorus. Science 323:1014-1015. DOI: 10.1126/science.1167755

Diez-Quijada L, Puerto M, Gutierrez-Praena D, Llana-RuizCabello M, Jos A, Camean AM, 2019. Microcystin-RR: Occurrence, content in water and food and toxicological studies. A review. Environ. Res. 168:467-489. DOI: 10.1016/j.envres.2018.07.019

Edwards C, Beattie KA, Scrimgeour CM, Codd GA, 1992. Identification of anatoxin-a in benthic cyanobacteria (bluegreen-algae) and in associated dog poisoning at Loch Insh, Scotland. Toxicon 30:1165-1175. DOI: 10.1016/00410101(92)90432-5

Faassen EJ, Harkema L, Begeman L, Lurling M, 2012. First report of (homo)anatoxin-a and dog neurotoxicosis after ingestion of benthic cyanobacteria in The Netherlands. Toxicon 60:378-384. DOI: 10.1016/j.toxicon.2012.04.335

Fastner J, Beulker C, Geiser B, Hoffmann A, Kroger R, Teske K, Hoppe J, Mundhenk L, Neurath H, Sagebiel D, Chorus I, 2018. Fatal neurotoxicosis in dogs associated with tychoplanktic, anatoxin-a producing Tychonema sp in mesotrophic Lake Tegel, Berlin. Toxins 10:11. DOI: $10.3390 /$ toxins 10020060
Gallina N, Salmaso N, Morabito G, Beniston M, 2013. Phytoplankton configuration in six deep lakes in the periAlpine region: are the key drivers related to eutrophication and climate? Aquat. Ecol. 47:177-193. DOI: 10.1007/s10452-013-9433-4

Huisman J, Codd GA, Paerl HW, Ibelings BW, Verspagen JMH, Visser PM, 2018. Cyanobacterial blooms. Nat. Rev. Microbiol. 16:471-483. DOI: 10.1038/s41579-018-0040-1

Ibelings BW, Backer LC, Kardinaal WEA, Chorus I, 2014. Current approaches to cyanotoxin risk assessment and risk management around the globe. Harmful Algae 40:63-74. DOI: 10.1016/j.hal.2014.10.002

Kellmann R, Ploux O, Neilan BA, 2013. Neurotoxic alkaloids from cyanobacteria. In: Natural Products. Ramawatt KG, Merillon JM, eds. Springer-Verlag, Berlin Heidelberg. DOI: 10.1007/978-3-642-22144-6_47

Kurmayer R, Christiansen G, Fastner J, Börner T, 2004. Abundance of active and inactive microcystin genotypes in populations of the toxic cyanobacterium Planktothrix spp. Environ. Microbiol. 6:831-841. DOI: 10.1111/j.14622920.2004.00626.x

Mantzouki E, Campbell J, van Loon E, Visser P, Konstantinou I, Antoniou M, et al, 2018a. Data Descriptor: A European Multi Lake Survey dataset of environmental variables, phytoplankton pigments and cyanotoxins. Sci. Data 5:180226. DOI: $10.1038 /$ sdata.2018.226

Mantzouki E, Lurling M, Fastner J, Domis LD, Wilk-Wozniak E, Koreiviene J, et al, 2018b. Temperature effects explain continental scale distribution of cyanobacterial toxins. Toxins 10:156. DOI: 10.3390/toxins10040156

Meriluoto J, Blaha L, Bojadzija G, Bormans M, Brient L, Codd GA, et al, 2017a. Toxic cyanobacteria and cyanotoxins in European waters - recent progress achieved through the CYANOCOST Action and challenges for further research. Adv. Oceanogr. Limnol. 8:161-178. DOI: 10.4081/aiol. 2017.6429

Meriluoto J, Spoof L, Codd G, 2017b. Handbook of Cyanobacterial Monitoring and Cyanotoxin Analysis. Meriluoto J, Spoof L, Codd GA, Eds.; Wiley: Chichester, UK

Metcalf JS, Codd GA, 2012. Cyanotoxins. In: Ecology of Cyanobacteria II. Springer, Dordrecht.

Mosello R, Ambrosetti W, Arisci S, Bettinetti R, Buzzi F, Calderoni $\mathrm{A}$, et al, 2010. Evoluzione recente della qualità delle acque dei laghi profondi subalpini (Maggiore, Lugano, Como, Iseo e Garda) in risposta alle pressioni antropiche e alle variazioni climatiche. Biologia Ambientale 24:167-177.

Mosello R, Calderoni A, De Bernardi R, 1997. [Le indagini sulla evoluzione dei laghi profondi sudalpini svolte dal C.N.R. Istituto italiano di Idrobiologia].[Article in Italian]. Doc. Ist. Ital. Idrobiolog. 61:19-32.

Moss B, Kosten S, Meerhoff M, Battarbee RW, Jeppesen E, Mazzeo N, et al, 2011. Allied attack: climate change and eutrophication. Inland Waters 1:101-105. DOI: 10.5268/IW1.2.359

Neilan BA, Pearson LA, Muenchhoff J, Moffitt MC, Dittmann E, 2013. Environmental conditions that influence toxin biosynthesis in cyanobacteria. Environ. Microbiol. 15:12391253. DOI: 10.1111/j.1462-2920.2012.02729.x

Pareeth S, Bresciani M, Buzzi F, Leoni B, Lepori F, Ludovisi A, et al, 2017. Warming trends of perialpine lakes from 
homogenised time series of historical satellite and in-situ data. Sci. Total Env. 578:417-426. DOI: 10.1016/j.scitotenv. 2016.10.199

R Core Team, 2019. R: A language and environment for statistical computing (v. 3.6.0). R Foundation for Statistical Computing, Wien, Austria.

Rigosi A, Carey CC, Ibelings BW, Brookes JD, 2014. The interaction between climate warming and eutrophication to promote cyanobacteria is dependent on trophic state and varies among taxa. Limnol. Oceanogr. 59:99-114. DOI: 10.4319/lo.2014.59.1.0099

Rogora M, Buzzi F, Dresti C, Leoni B, Lepori F, Mosello R, et al, 2018. Climatic effects on vertical mixing and deep-water oxygen content in the subalpine lakes in Italy. Hydrobiologia 824:33-50. DOI: 10.1007/s10750-018-3623-y

Rohrlack T, Edvardsen B, Skulberg R, Halstvedt CB, Utkilen HC, Ptacnik R, Skulberg OM, 2008. Oligopeptide chemotypes of the toxic freshwater cyanobacterium Planktothrix can form subpopulations with dissimilar ecological traits. Limnol. Oceanogr. 53:1279-1293. DOI: 10.4319/lo.2008.53.4.1279

Rounge TB, Rohrlack T, Decenciere B, Edvardsen B, Kristensen T, Jakobsen KS, 2010. Subpopulations differentiation associated with nonribosomal peptide synthetase gene cluster dynamics in the cyanobacterium Planktothrix spp. J. Phycol. 46:645-652. DOI: 10.1111/j.1529-8817.2010.00856.x

Salmaso N, Buzzi F, Capelli C, Cerasino L, Leoni B, Lepori F, Rogora M, 2020. Responses to local and global stressors in the large southern perialpine lakes: Present status and challenges for research and management. J. Great Lakes Res. DOI: 10.1016/j.jglr.2020.01.017

Salmaso N, 2019. Effects of habitat partitioning on the distribution of bacterioplankton in deep lakes. Front. Microbiol. 10. DOI: 10.3389/fmicb.2019.02257

Salmaso N, Albanese D, Capelli C, Boscaini A, Pindo M, Donati C, 2018a. Diversity and cyclical seasonal transitions in the bacterial community in a large and deep perialpine lake. Microb. Ecol. 76:125-143. DOI: 10.1007/s00248-017-1120-x
Salmaso N, Boscaini A, Capelli C, Cerasino L, 2018b. Ongoing ecological shifts in a large lake are driven by climate change and eutrophication: evidences from a three-decade study in Lake Garda. Hydrobiologia 824:177-195. DOI: 10.1007/s10750-017-3402-1

Salmaso N, Cerasino L, Boscaini A, Capelli C, 2016. Planktic Tychonema (Cyanobacteria) in the large lakes south of the Alps: phylogenetic assessment and toxigenic potential. Fems Microbial Ecol. 92. DOI: 10.1093/femsec/fiw155

Salmaso N, Copetti D, Cerasino L, Shams S, Capelli C, Boscaini A, et al, 2014. Variability of microcystin cell quota in metapopulations of Planktothrix rubescens: causes and implications for water management. Toxicon 90:82-96. DOI: 10.1016/j.toxicon.2014.07.022

Shams S, Capelli C, Cerasino L, Ballot A, Dietrich DR, Sivonen K, Salmaso N, 2015. Anatoxin-a producing Tychonema (Cyanobacteria) in European waterbodies. Water Research 69:68-79. DOI: 10.1016/j.watres.2014.11.006

Spoof L, Arnaud C, 2017. Appendix 3: Tables of microcystins and nodularins. In: Meriluoto J, Spoof L, Codd GA (eds.), Handbook of cyanobacterial monitoring and cyanotoxin analysis. Wiley, Chichester.

Visser PM, Verspagen JMH, Sandrini G, Stal LJ, Matthijs HCP, Davis TW, et al, 2016. How rising $\mathrm{CO}_{2}$ and global warming may stimulate harmful cyanobacterial blooms. In Harmful Algae 54:145-159. DOI: 10.1016/j.hal.2015.12.006

Wimmer KM, Strangman WK, Wright JLC, 2014. 7-Deoxydesulfo-cylindrospermopsin and 7-deoxy-desulfo12-acetylcylindrospermopsin: Two new cylindrospermopsin analogs isolated from a Thai strain of Cylindrospermopsis raciborskii. Harmful Algae 37:203-206. DOI: 10.1016/j.hal.2014.06.006

Wood, S, 2006. Generalized additive models: An introduction with R. Chapman and Hall/CRC.

Zuur AF, Ieno EN, Walker NJ, Saveliev AA, Smith GM, 2009. Mixed effects models and extensions in ecology with R. Springer, New York. 